\title{
PROGRESS IN THE REALIZATION OF THE PROJECT FON-DUSHANBE CATALOGUE
}

\author{
A.Mullo-Abdolov ${ }^{1}$, H.Relke ${ }^{2}$, G.Kokhirova ${ }^{1}$, Q.Yuldoshev ${ }^{3}$, Yu.Protsyuk ${ }^{4}$, V. Andruk ${ }^{5}$ \\ ${ }^{1}$ Institute of Astrophysics of AS of Republic of Tajikistan, Dushanbe, Tajikistan, \\ aziz.sherzod@gmail.com \\ ${ }^{2}$ Walter Hohmann Observatory, Essen, Germany, helena_relke@yahoo.com \\ ${ }^{3}$ Ulugh Beg Astronomical Institute UAS, Tashkent, Uzbekistan,qudratillo@astrin.uz \\ ${ }^{4}$ Research Institute "Mykolaiv Astronomical Observatory", Mykolaiv, Ukraine, \\ yuri@nao.nikolaev.ua \\ ${ }^{5}$ Main Astronomical Observatory NASU, Kiev, Ukraine, andruk@mao.kiev.ua
}

\begin{abstract}
Since May 2018 the process of the scanning and processing of photographic plates from the archive of the Institute of Astrophysics Academy of Sciences of Tajikistan has begun. It is a matter of approximately 1560 photographic plates in the sky zones from -8 to +90 degrees that were exposed for the FON project in the Hissar observatory (HisAO) during 1985-1992. The plates are digitized by using of the scanner Microtek ScanMaker 1000XL Plus with the resolution of $1200 \mathrm{dpi}$. The size of the photographic plates is $8^{\circ} \times 8^{\circ}$ or $30 \times 30 \mathrm{~cm}$, the size of the digitized images is $13000 \times 13000 \mathrm{px}$. So far the first results of the processing of the 71 plates of zero zone and the 58 plates of 64,68 and 72 zones were obtained. The errors in the definition of equatorial coordinates and B-magnitudes for the stars in the range of $5^{\mathrm{m}}$ $17^{\mathrm{m}}$ are the following: $\sigma_{\alpha \delta}= \pm 0.33^{\prime \prime}$ and $\sigma_{\mathrm{B}}= \pm 0.12^{\mathrm{m}}$. The differences between the calculated positions and Bmagnitudes and the reference one from the Tycho 2 catalogue are $\sigma_{\alpha \delta}= \pm 0.12$ " and $\sigma_{\mathrm{BT}}= \pm 0.19^{\mathrm{m}}$ respectively. The difference between the calculated and the photoelectric Bmagnitudes equals $\sigma \mathrm{B}= \pm 0.15^{\mathrm{m}}$. In the realization of the "FON-Dushanbe catalogue" project five astronomical institutions are involved: Institute of Astrophysics of AS of Republic of Tajikistan; Walter Hohmann Observatory, Essen, Germany; Ulugh Beg Astronomical Institute UAS, Uzbekistan; Research Institute "Mykolaiv Astronomical Observatory", Ukraine and Main Astronomical Observatory NASU, Ukraine.
\end{abstract}

Keywords: scanning, processing of digitized plates, FON project, astrometry, photometry, data analysis

АБСТРАКТ. В травні 2018 року за програмою ФОН розпочато процес масового сканування та обробки фотографічних платівок із колекції Інституту астрофізики АН Республіки Таджикистан. За період 1985-1992 рр. в зонах від $-8^{\circ}$ до $+90^{\circ}$ експоновано близько 1560 платівок розміром $8^{\circ} \times 8^{\circ}$. Платівки оцифровуються за допомогою сканера Microtek ScanMaker 1000XL Plus, режим сканування - 1200 dpi, розмір платівок - 30х30 см або 13000x13000 pх. Отримано перші результати із обробки 71 платівки нульової зони та 58 платівок 64, 68 і 72 зон. Для фотометричного інтервалу В-зоряних величин від $5^{\mathrm{m}}$ до $17^{\mathrm{m}}$ значення похибок визначення екваторіальних координат та В-зоряних величин такі: $\sigma_{\alpha \delta}=0.33$ " и $\sigma_{\mathrm{B}}=$ $0.12^{\mathrm{m}}$. Сходимість між обчисленими нами та опорними положеннями із каталогу Тусho2 $є$ такою: $\sigma_{\alpha \delta}=$ $0.12^{\prime}, \sigma_{\mathrm{BT}}=0.19^{\mathrm{m}}$, а сходимість 3 фотоелектричними зоряними В-величинами дорівнює $\sigma_{\mathrm{B}}=0.14^{\mathrm{m}}$. В обробці платівок та створенні каталога ФОН-Душанбе приймають участь п'ять астрономічних закладів: Інститут астрофізики АН Республіки Таджикистан, Обсерваторія ім. Вальтера Хоманна в Ессені (Німеччина), Астрономічний інститут ім. Улугбека АН Республіки Узбекистан, НДІ "Миколаївська астрономічна обсерваторія (Україна) та Головна астрономічна обсерваторія НАН України.

Ключові слова: сканування, обробка оцифрованих платівок, програма ФОН, астрометрія, фотометрія, аналіз даних

\section{Introduction}

The plan of the photographic survey of the Northern Sky (FON) was proposed in 1976 by the scientists of GAO of USSR G. Kolchinski and A.B. Onegina (Kolchinsky, 1977; Pakuliak, 2016). The idea of the project arose after the acquisition by several observatories of the USSR of identical wide-angle astrographs of the company Karl Zeiss (Jena) with the aperture of $40 \mathrm{~cm}$ and the focal lengths of 2 or 3 meters. The project FON was attended by six observatories: Main Astronomical observatory of Ukraine (Goloseevo), Zvenigorod observatory of Russia, Hissar observatory of Tadjikistan, Abastumani observatory of Georgia, Zelenchuk observatory of Russia and Kitab observatory of Uzbekistan. The northern sky should be photographed four times with an overlaping. The Hissar astronomical observatory (HisAO) of the Institute of Astrophysics of AS of Tajikistan also participated in the realisation of the project FON. Regular observations began in 1985 and lasted until 1992. Hamburg O.E., Relke 
E.V., Tsygankova M.I., Mullo-Abdolov A. S., Kiselev N.N. took part in the observations. In total, 1578 photographic plates were exposed. The 1560 of which were suitable for the processing. Thanks to the support of the Academy of Sciences of RT the Institute acquired a professional scanner, which allows the scanning of the photoplates whith the size of $30 \times 30 \mathrm{~cm}$ (Mullo-Abdolov, 2017, Rahimi, 2018). In 2017 the scanner was placed on a specially built platform. With the help of the scanner it is planned to digitize the photographic plates exposed for the project FON. The digitized images will be processed with the goal to create a FON-Dushanbe catalogue with exact positions and B-magnitudes of stars, galaxies and other objects. The task is solved together with colleagues from Walter Hohmann Observatory, Essen, Germany; Ulugh Beg Astronomical Institute UAS, Uzbekistan; Research Institute "Mykolaiv Astronomical Observatory", Ukraine and Main Astronomical Observatory NASU, Ukraine. Earlier, in 2016, within the framework of the UkrVO project (Vavilova, 2012; Vavilova, 2016; Vavilova, 2017) the Kiev part of the program FON was performed (Andruk, 2015b; Andruk, 2016a; Andruk, 2016b) and in 2017 the Kitab part of the project FON was done (Yuldoshev, 2017a; Yuldoshev, 2017b). For the future the creation of the common catalogue of the FON project is planed (Andruk, 2017b). This future FON-catalogue will contain also the U, V values, which will be obtained after processing of digitized photographic plates of $1.2-\mathrm{m}$ telescope in Baldone (Eglitis, 2016; Eglitis, 2017; Eglitis, 2018).

\section{First results of processing of the FON-Dushanbe} zones

In May 2018 the 71 photographic plates of zero zone and 58 plates of the 64,68 and 72 zones were digitized and processed. The size of one plate is 8 degrees along the declination and $8 x \cos \delta$ degrees along the right ascension. So the 90 plates are necessary for the full filling of zero zone with two overlapping. The filling of the sky by the stars of $\mathrm{B}=10^{\mathrm{m}}$ magnitude for zero and near polar zones is showed in the Figure 1 in the form of sky maps. The sequence and principles of the processing of wide-angle digitized plates with the purpose of the obtaining of equatorial coordinates and visual B-magnitudes of registered objects were published in the following works (Andruk, 2015a; Andruk, 2017a).

\subsection{Astrometry}

Astrometric reduction of the digitized photographic plates with the size of $8 \times 8$ degrees is carried out in two steps: the investigation of the systematic errors of the scanner $\Delta \alpha$ and $\Delta \delta$ and then the reduction of rectangular coordinates $\mathrm{X}, \mathrm{Y}$ of all objects in the system of equatorial coordinates $\alpha, \delta$ of Tycho- 2 catalogue. At the both steps of data processing the tangential coordinates $\xi, \eta$ are calculated by the method of the smallest squares using the formula:
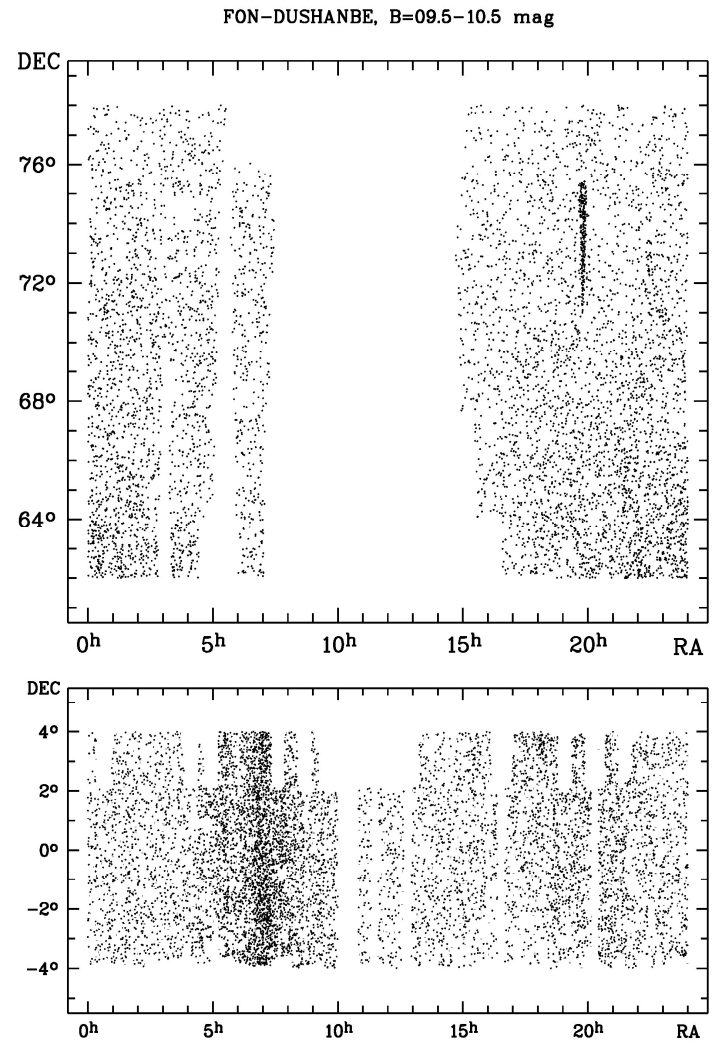

Figure 1: Sky maps. The filling of the sky areas of zero (bottom) and near polar (top) zones of the FON-Dushanbe project with the stars of $\mathrm{B}=10^{\mathrm{m}}$ magnitude

$$
\begin{gathered}
\xi_{i}=a_{1}+a_{2} X_{i} f_{i}+a_{3} Y_{i} f_{i}+a_{4} R_{i} m_{i}+a_{5} f_{i}+\sum b_{l m} X_{i}^{l} Y_{i}^{m}, \\
(l=0 \div 6, m=0 \div 6, l+m=n, n=1 \div 6) \\
\eta_{i}=c_{1}+c_{2} X_{i} f_{i}+c_{3} Y_{i} f_{i}+c_{4} R_{i} m_{i}+c_{5} f_{i}+\sum d_{l m} X_{i}^{l} Y_{i}^{m}, \\
(l=0 \div 6, m=0 \div 6, l+m=n, n=1 \div 6)
\end{gathered}
$$

where $\mathrm{i}=1,2, \ldots \mathrm{N}$ - number of stars from the TYCHO-2 catalogue on the digitized plate; $\mathrm{X}_{\mathrm{i}}, \mathrm{Y}_{\mathrm{i}}$ и $\mathrm{R}_{\mathrm{i}}$ - coordinates and distances of star images relative to the center of the plate; $m_{i}$ - instrumental photometric star values; $f_{i}-$ diameters of star images; coefficients $\mathrm{a}_{2}, \mathrm{a}_{3}, \mathrm{a}_{4}$ and $\mathrm{c}_{2}, \mathrm{c}_{3}, \mathrm{c}_{4}$ are responsible for the coma; coefficients $\mathrm{a}_{5}, \mathrm{c}_{5}-$ take into account the influence of the brightness equation (these coefficients are calculated separately); the $b_{l m}$ и $d_{l m}$ are the coefficients of the full polynomial of degree six (altogether 27 members), which describe in a general case optical aberrations of the telescope complicated by systematic errors of the scanner. The first results of the processing of 58 plates near polar zones and 71 plates of zero zone of the FONDushanbe project are show in the Figure 2. 

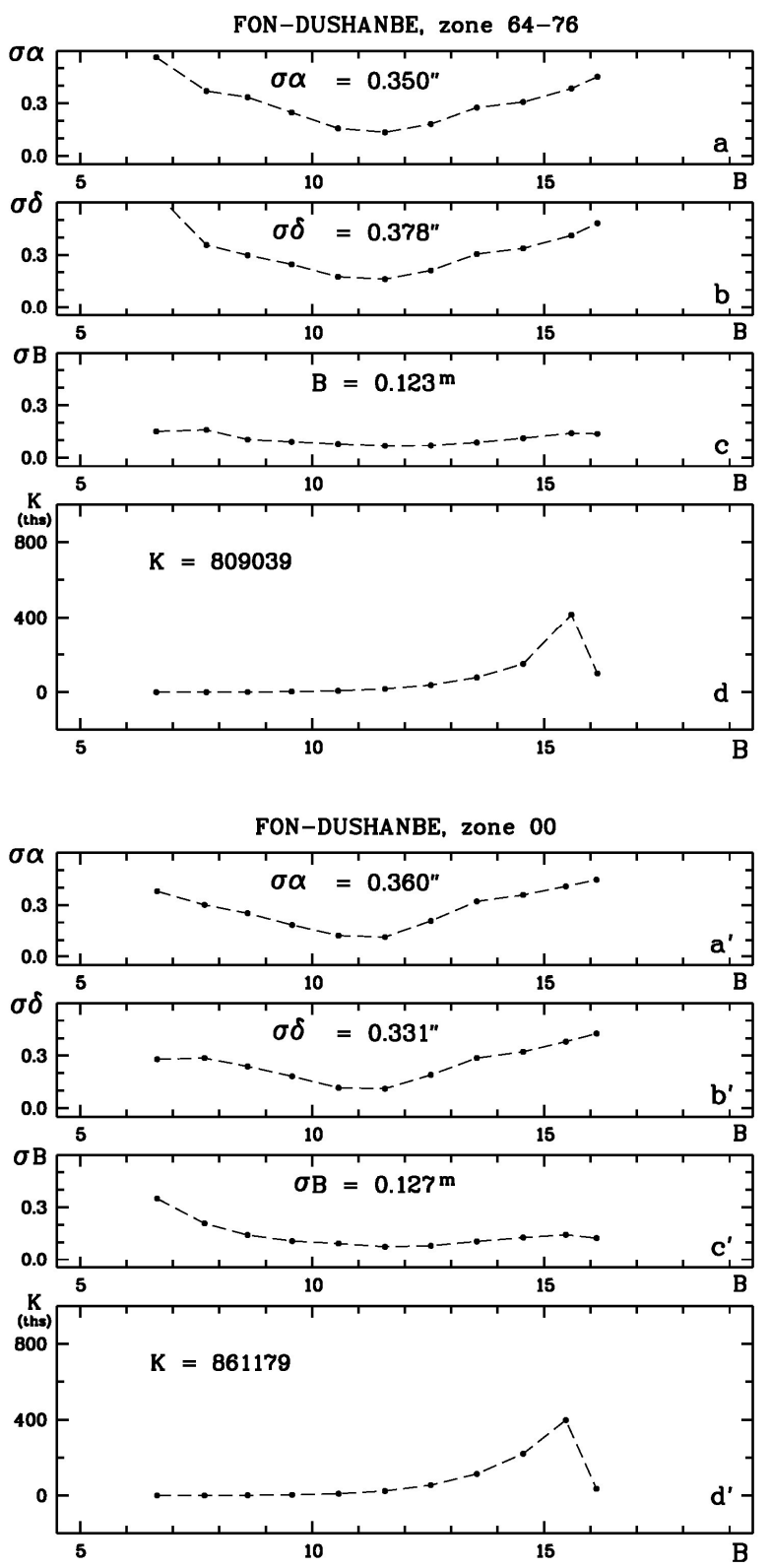

Figure 2: The trend of internal errors for equatorial coordinates and B-magnitudes as well as the number of stars relative to the intervals of the B-magnitudes of the FONDushanbe catalogue. The error information for the near polar $(64,68,72)$ zones is presented on the upper panels a, b, c and $\mathrm{d}$; for the zero zone - on the lower panels a', b', c' and d'.

The coordinates of the stars and galaxies are obtained in the system of the Tycho- 2 catalogue, the B-magnitudes - in the system of photoelectric standards. The mean observation epoch of the FON-Dushanbe catalogue is1990.5. The values of the internal errors of equatorial coordinates and Bmagnitudes of stars and galaxies are equal: $\sigma \alpha \delta=0.33 "-$ $0.36^{\prime \prime}$ and $\sigma \mathrm{B}=0.13^{\mathrm{m}}$ respectively. The distribution of errors of equatorial coordinates of the FON-Dushanbe catalogue relative to the reference Tycho- 2 catalogue for near polar zones and zero zone are presented in the Figure 3.
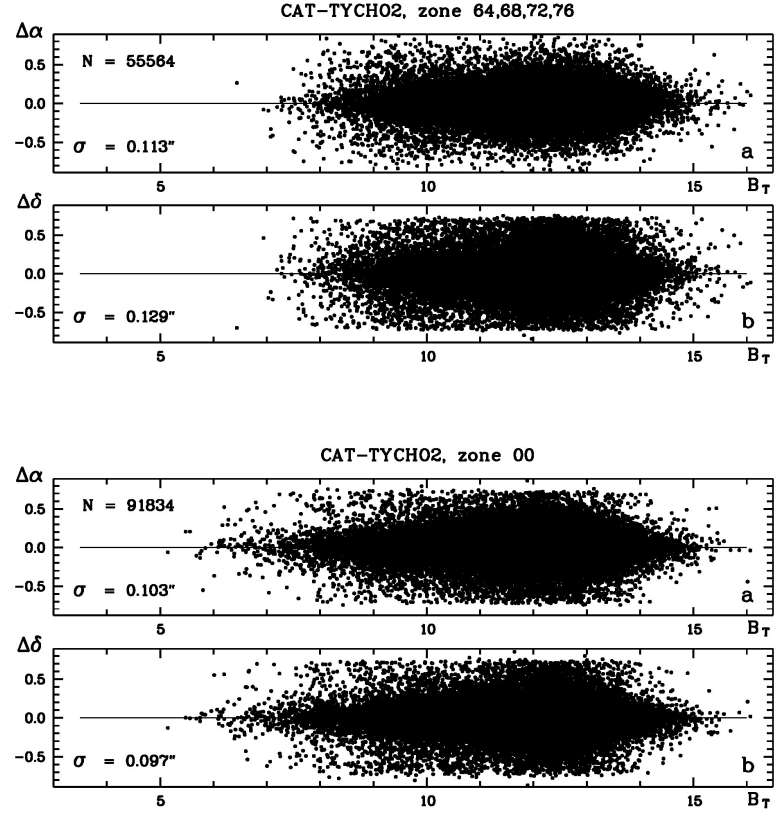

Figure 3: The distribution of mean squared errors of equatorial coordinates of the FON-Dushanbe catalogue relative to the reference Tycho-2 catalogue for the near polar zones (panels $\mathrm{a}, \mathrm{b}$ ) and the zero zone (panels a', b').

\subsection{Photometry}

The photoelectric $B_{p e}$ values of stars from a specially created catalogue were used as photometric standards for the construction of characteristic curves for each digitized photographic plate (Relke, 2015; Andruk, 2017a). The errors of differences $\Delta \mathrm{B}$ between the calculated by us $\mathrm{B}$-magnitudes and photoelectric $\mathrm{B}_{\mathrm{pe}}$ values of stars for more than 2370 stars are equal to $\sigma_{\mathrm{B}}=0.14^{\mathrm{m}}$. The Figure 4 illustrates the trend of differences $\Delta \mathrm{B}$ relative to photoelectric values $\mathrm{B}$ and $\mathrm{B}-\mathrm{V}$.

\subsection{Comparison with other catalogues}

A separated independent study of astrometric and photometric properties of the zero zone for three catalogues of the FON project (FON-Kiev, FON-Kitab and FON-Dushanbe) were made by special method (Akhmetov, 2016) in the work, which was also presented on the Gamov conference 2018 and was published in the same conference proceeding (Akhmetov, 2018).

\section{Conclusion}

At the end of June 2018 about 150 photographic plates of zero (00) and polar $(64,68,72$ and 76) zones of the FON-Dushanbe photographic archive were digitized and processed. In parallel these digitized plates are used for the searching of asteroids and comets (Yizhakevych, 2018; Shatokhina, 2017; Shatokhina, 2018). In the Astrophysics Institute of the Academy of Sciences of Tajikistan the work on scanning of plates continues. By the end of 2019 using the results of the processing of all digitized photographic plates (about 1560) it is planned to obtain the FON-Dushanbe catalogue. 

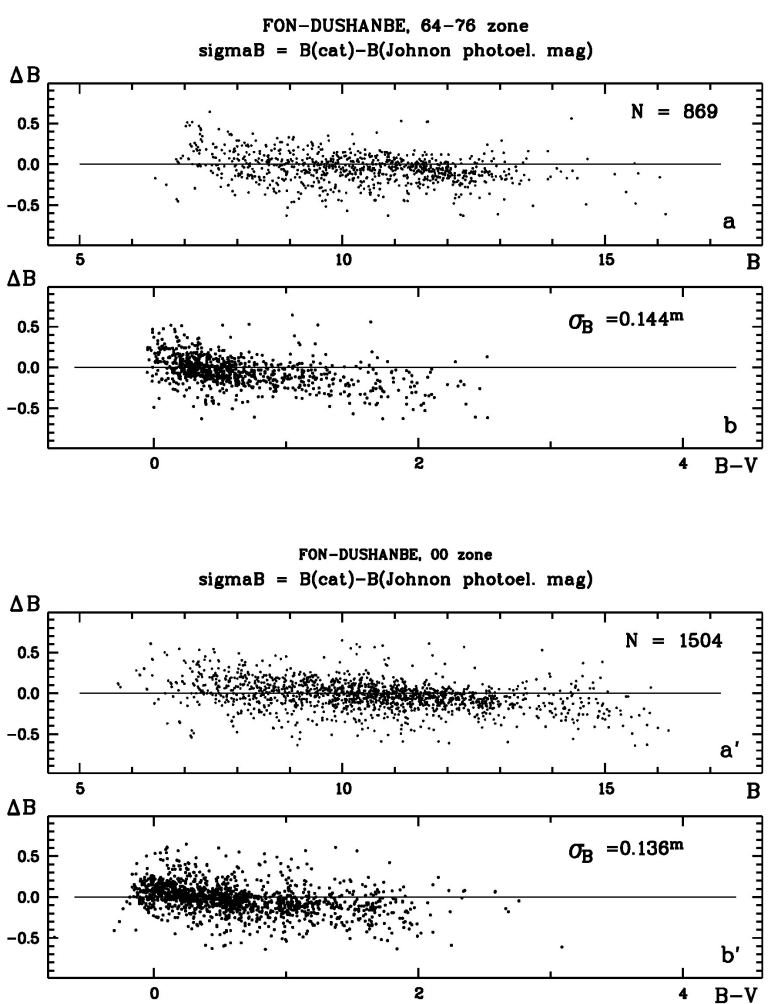

Figure 4: The error distribution of photometry of the FON-Dushanbe catalogue relative to the reference system of the photoelectric B and B-V measurements of stars for the near polar zones (top panels $\mathrm{a}, \mathrm{b}$ ) and zero zone (panels a', b').

Acknowledgements. The authors are thankful to academician Farhod Rahimi, the President of Academy of Sciences of the Republic of Tajikistan, for the supporting of the project "FON-Dushanbe catalogue".

\section{References}

Akhmetov V.S.: 2016, Odessa Astron. Publ., 29, 116. Akhmetov V.S. Khlamov S.V., Andruk V.M., Protsyuk Yu.I.: 2018, Odessa Astron. Publ., 31, .

Andruk V.M., Pakuliak L.K., Golovnya V.V. et al.: 2015, arxiv.org/abs/1512.05535.
Andruk V.M., Pakuliak L.K., Golovnia V.V. et al.: 2015, Odessa Astron. Publ., 28, 192.

Andruk V.M., Golovnia V.V., Ivanov G.A. et al.: 2016, Kinem. Phys. Cel. Bodies, 32, N1, 38.

Andruk V.M., Pakuliak L.K., Golovnia V.V. et al.: 2016, Kinem. Phys. Cel. Bodies, 32, N5, 260.

Andruk V.M., Pakuliak L.K., Golovnia V.V. et al.: 2017, Scince and Innovation, 13a, 17.

Andruk V., Yuldoshev Q., Eglitis I. et al.: 2017, Odessa Astron Publ., 30, 159.

Eglitis I., Eglite M., Pakuliak L.K., Andruk V.M.: 2016, Odessa Astron Publ., 29, 126.

Eglitis I., Andruk V.: 2017, Open Astronony, 26, 7.

Eglitis I., Eglite V., Andruk V., Protsyuk Yu. et al: 2018, Odessa Astron Publ., 31, .

Kolchinsky I.G., Onegina A.B.: 1977, Astrometry and Astrophysics, 33, 11.

Mullo-Abdolov A., Kokhirova A., Relke H. et al.: 2017, Odessa Astron Publ., 30, 186.

Pakuliak L.K., Andruk V.M., Golovnia V.V. et al.: 2016, Odessa Astron. Publ., 29, 132.

Rahimi F., Mullo-Abdolov A.Sh., Kokhirova G.I. et al.: 2018, Reports AS RT, 60, №2, 144.

Relke E., Protsyuk Yu.I., Andruk V.M.: 2015, Odessa Astron. Publ., 28, 211.

Shatokhina S.V., Kazantseva L.V., Yizhakevych O.M. et al.: 2017, Odessa Astron. Publ., 30, 198.

Shatokhina S.V., Kazantseva L.V., Yizhakevych O.M., Andruk V.M.: 2018, Kinem. Phys. Cel. Bodies, 34, N5, 70.

Vavilova I.B., Pakulyak L.K., Shlyapnikov A.A. et al.: 2012, Kinem. Phys. Cel. Bodies, 28, N4, 85.

Vavilova I.B.: 2016, Odessa Astron. Publ., 29, 109.

Vavilova I.B., Yatskiv Ya.S., Pakuliak L.K.: 2017, IAUS, 325, 361.

Yizhakevych O.M., Mullo-Abdolov A.Sh., Relke H.V. et al.: 2018, Odessa Astron. Publ., 31, .

Yuldoshev Q.X., Muminov M.M., Ehgamberdiev Sh.A. et. al.: 2017, Odessa Astron Publ., 30, 205.

Yuldoshev Q.X., Ehgamberdiev Sh.A., Muminov M.M. et al.: 2017, Kinem. Phys. Cel. Bodies, 33, N5, 250. 